\title{
MEDIA DAN KRITIK SOSIAL (ANALISIS FRAMING PEMBERITAAN PEDAGANG KAKI LIMA CIHIDEUNG KOTA TASIKMALAYA PADA HARIAN UMUM KABAR PRIANGAN GRUP PIKIRAN RAKYAT PERIODE APRIL- SEPTEMBER 2017)
}

\author{
Fazrian Noor Romadhon \\ Program Magister Ilmu Komunikasi Universitas Jenderal Soedirman \\ Email: noorfazrian7@gmail.com
}

\begin{abstract}
Abstrak
Penelitian ini dilatarbelakangi oleh polemik PKL Cihideung Kota Tasikmalaya yang menimbulkan beberapa permasalahan seperti kemacetan, mengganggu hak pejalan kaki di trotoar, pedagang rumah toko yang terhalang oleh PKL, serta mengganggu pengguna kendaraan karena jalannya digunakan hampir setengah jalan untuk berjualan. Objek penelitian ini yaitu empat berita tentang PKL Cihideung yang diterbitkan Harian Umum Kabar Priangan pada periode April-September 2017. Penulis mengkajinya dengan menggunakan metode penelitian kualitatif interpretatif didukung pendekatan konstruksionis dengan menggunakan analisis data model framing Robert N. Entman. Selain itu, teknik pengumpulan data yang digunakan pada penelitian ini yaitu kajian dokumen (berita) dan wawancara. Hasil menunjukkan bahwa HU Kabar Priangan menempatkan keempat berita tersebut di halaman awal yang dinilai penting, menarik, berarti, juga untuk mudah mengingat. HU Kabar Priangan pula menempatkan PKL sebagai penyebab masalah secara kesepakatan, sedangkan pemerintah penyebab masalah secara peraturan yang dikritik melalui judul hingga kutipan-kutipan wawancara narasumber yang ditonjolkan sebagai bentuk kritik kepada pemerintah yang lambat dalam menangani dan menata PKL Cihideung
\end{abstract}

Kata kunci: PKL, media, framing, konstruksionis

\begin{abstract}
The background of this research is polemic of street vendors (PKL) Cihideung Kota Tasikmalaya that caused some problems, such as traffic jams, distrup the pedestrian right on the sidewalk, merchant who blocked by street vendors, as well as disrupt the vehicle users because the road is used almost halfway to sell. This research object is four news about PKL Cihideung published by HU Kabar Priangan in April-September 2017 period, using qualitative interpretive research method supported by constructionist approach by using framing model data analysis Robert N. Entman. In addition, data collection techniques used in this study is the study of documents (news) and Interview. The results shows that HU Kabar Priangan puts the four news on the start page. In the sense, the initial placement means that the four news is considered important, interesting, means, also to easily remember.HU Kabar Priangan also puts the street vendors as the cause of the problem by agreement, while the government causes the problem in a regulation that is criticized through the title to the excerpt of interview quotes from the speakers highlighted as a form of criticism to the slow government in handling and managing PKL Cihideung
\end{abstract}

Keywords: PKL, media, framing, constructionist 


\section{PENDAHULUAN}

Sudah sejak lama, media dan politik menjadi kesatuan dalam menyampaikan komunikasi politik. Perannya dinilai penting dalam suatu sistem politik untuk menyampaikan informasi maupun pesan-pesan, baik itu pada tataran suprastruktur ataupun infrastruktur politik. Maka dari itu, media juga jurnalis didalamnya menjadi salah satu komunikator profesional untuk menghubungkan aktor-aktor politik dengan warga negara.( H.I, A Rahman. (2007)

Dalam suatu negara demokrasi, komunikasi antar aktor-aktor politik dengan warga negara dinilai penting untuk dilakukan. Meski memang sulit dilakukan untuk berkomunikasi secara tatap muka langsung, komunikasi pada dewasa ini salah satunya termediasi melalui kehadiran media massa. Bahkan, media massa tidak hanya berperan sebagai sarana komunikasi semata. Jauh lebih dalamnya, berperan sebagai ruang publik yang interpretatif dan saling mempengaruhi.(Simarmata, (2014)

Salah satu persoalan publik yang diselesaikan melalui kebijakan pemerintah yang banyak menjadi sorotan media yaitu fenomena street vendors atau Pedagang Kaki Lima (PKL). Di beberapa kota, persoalan ini sudah menjadi persoalan yang penting untuk dikaji. Keberadaannya tidak sedikit menimbulkan kontradiktif di beberapa aspek, seperti tata ruang, legalitas, hingga peraturan daerah. Tidak hanya itu, tingkat kebutuhan masyarakat desa yang kian konsumtif, rendahnya penghasilan pada sektor pertanian, serta resiko usaha pertanian yang semakin besar, menjadikan masyarakat desa berbondong-bondong bekerja ke kota sebagai buruh ataupun berwirausaha kecil-kecilan dengan modal yang minim.(Ahmad Ibrahim. (2004) Sehingga tidak heran, pertumbuhan PKL seringkali terus meningkat.

Salah satu daerah yang hingga saat ini mengalami perkembangan PKL yaitu Kota Tasikmalaya. Keberadaannya tersebar di beberapa lokasi juga tempat-tempat publik, seperti taman kota, kawasan olahraga, hingga pusat perbelanjaan HZ Mustafa. Tidak jarang pula, keberadaannya seringkali menimbulkan kegaduhan seperti ruang pejalan kaki terganggu oleh adanya PKL, pedagang yang menempati rumah toko merasa terhalang oleh adanya kios-kios PKL, hingga petugas parkir yang kecewa karena pengendara motor saat ini lebih memilih parkir di tempat lain karena sempit.( Jani Noor, HU Kabar Priangan, 2017)

Salah satu kawasan yang dipadati oleh PKL yaitu pusat perbelanjaan Cihideung. Para PKL berjualan di bahu kanan kiri jalan hingga menimbulkan kemacetan yang cukup panjang. Tentu, pengendara pun harus berhati-hati, juga mengurangi kecepatan laju kendaraan. Disatu sisi, pemerintah daerah sudah melarang para PKL yang berjualan di jalan Cihideung untuk tidak berjualan di pinggir jalan. Akan tetapi yang membingungkan, disisi lain pemerintah daerah justru memberikan bantuan gerobak permanen untuk berjualan bagi para PKL di jalan Cihideung. Akibatnya, penempatan gerobak para pedagang PKL yang menguasai setengah badan tersebut, menutupi sejumlah toko serta menimbulkan kemacetan setiap harinya. (Wartamerdeka.com, Pemkot Tasik Dinilai Aneh, PKL di Hazet Dilarang Berjualan Tapi di Cihideung Diberi Bantuan, diakses pada 05 September 2017)

Melihat hal itu, ditengah era kebebasan media pada saat ini, fungsi media tidak hanya sekedar menginformasikan semata. Melainkan, media menjadi penghubung juga wahana untuk membicarakan, mengkoridori, serta mengkonstruksi isu-isu yang terjadi di masyarakat.(Insist. (2015) Demikian dengan pers yang merupakan salah satu produk dari 
media, merupakan suatu lembaga kemasyarakatan yang bersama-sama dengan subsistem lainnya. Sehingga, faktor dipengaruhi dan mempengaruhi pun sering terjadi. Tidak heran, eksistensi pers ditentukan oleh falsafah juga sistem politik di negara pers tersebut hidup.(Uchjana Effendy, (2005)

Jauh lebih dalamnya lagi, pers berperan sebagai penginterpretasi (interpreter) untuk menafsirkan arti pada suatu isu. Dalam artian, tugas pers lainnya yang tidak kalah urgent yaitu menganalisis berita. Maka dari itu, peran pers sebagai pengkritik pemerintah (watchdog) adalah perlu. Watchdog adalah proses penyelidikan independen oleh pers terhadap kegiatan pemerintah, bisnis, dan lembaga publik dengan cara mendokumentasikan, menanyakan, dan menginvestigasi kegiatan tersebut untuk disampaikan kepada masyarakat dan pejabat terkait mengenai isu yang sedang berkembang.Hal tersebut penting guna menjadi barometer demi terwujudnya suatu kebijakan yang bijaksana dan menjadi representative of the public.(Ishwara, 2016) Dengan demikian, konsep media, pers, dan jurnalisme menjadi landasan fundamental upaya mengkaji dan menganalisis dalam penelitian ini ditambah dengan pengembangan kajian lainnya yang dinilai relevan. Konsep ini penting karena penelitian ini berfokus pada bidang media dan jurnalisme.

Surat kabar merupakan salah satu jenis dari media massa cetak. Fungsinya selain sebagai penyampai informasi, edukasi, hiburan, dan persuasif, pun sebagai alat untuk mempengaruhi serta menjadi alat kontrol sosial yang konstruktif. (Ardianto, 2007) Biasanya, surat kabar terbit setiap hari dengan menyajikan berita-berita yang telah diperoleh oleh wartawan pada hari sebelumnya, ataupun suatu hal yang akan terjadi. Dalam pemberitaan surat kabar, biasanya wartawan menggunakan prinsip what, when, where, who, why, how $(5 \mathrm{~W} 1 \mathrm{H})$ dengan memperhatikan 11 kategori nilai berita, diantaranya keluarbiasaan (unusualness), kedekatan (proximity), kebaruan (newness), akibat (impact), aktual (timeliness), informasi (information), konflik (conflict), orang penting (prominence), ketertarikan manusia (human interest), dan seks (sex). (Nur Amaliyah, 2016) Maka dari itu, surat kabar yang merupakan produk dari media dan jurnalisme menjadi kajian penting yang akan digunakan upaya menganalisis dan mengkaji pada penelitian ini. Konsep ini penting, karena objek utama pada penelitian ini yaitu surat kabar.

Salah satunya polemik PKL Cihideung diatas, salah satunya diterbitkan secara berkala dari bulan April-September 2017 oleh Harian Umum Kabar Priangan. HU Kabar Priangan tercatat empat kali memberitakan dikemas dengan framing yang berbeda-beda. Dari keempat berita tersebut, penulis melihat adanya kesamaan yang ingin dicari dan dibentuk oleh media, terlebih pada soal pembentukan regulasi/ atau kebijakan PKL agar tidak menimbulkan persoalan yang berkepanjangan. Bahkan, dari kedua tersebut, peran media untuk mempengaruhi sistem politik dalam pembuatan kebijakan sangat terlihat melalui adanya temuan-temuan di lapangan yang saling bertentangan dan menimbulkan masalah baru, hingga akhirnya dikonstruk melalui framing yang secara tidak langsung menekan pemerintah untuk segera bertindak membenahi hal tersebut.

Hal itu pula yang dilakukan media untuk mengkonstruksi pemberitaan. Konsep konstruksionisme pertama kali diperkenalkan oleh seorang Sosiolog Interpretatif bernama Peter L. Berger. Melalui konsepnya, Peter L. Berger memandang bahwa framing dan konstruksi merupakan satu kesatuan untuk melihat posisi dan pandangan terhadap media dan 
teks berita. Pandangan tersebut akan terlihat melalui kolaborasi antara media, wartawan, dan berita yang dilihat.( Poloma, 1984)

Beberapa poin penting paradigma konstruksionis, diantaranya:

1. Fakta merupakan konstruksi realitas. Kebenaran suatu fakta bersifat relatif, berlaku sesuai konteks tertentu

2. Media sebagai agen konstruksi pesan

3. Berita tidak mungkin merupakan cermin dan refleksi dari realitas. Karena berita yang terbentuk merupakan konstruksi atas realita

4. Berita bersifat subjektif yaitu opini tidak dapat dihilangkan. Karena ketika meliput, wartawan melihat dengan perspektif dan pertimbangan subjektif

5. Wartawan sebagai partisipan yang menjembatani keragaman subjektifitas pelaku sosial

6. Nilai, etika, atau keberpihakan wartawan tidak dapat dipisahkan dari proses peliputan dan pelaporan suatu peristiwa

7. Nilai, etika, dan pilihan moral merupakan bagian yang tak terpisahkan dari suatu penelitian

8. Khalayak mempunyai penafsiran sendiri yang bisa jadi berbeda dari pembuat berita. (Eriyanto, 2009)

Media dan konstruksi realitas adalah satu kesatuan yang tidak bisa terpisahkan. Keduanya saling berkaitan dan berpengaruh satu sama lain. Media yang merupakan alatnya, sedangkan realitas merupakan hasil olah sudut pandang wartawan yang tercipa lewat konstruksi.(Eriyanto, 2009) Media, khususnya media massa, memiliki peran penting untuk untuk membentuk makna bahkan citra bagi masyarakat. Konstruksi realitas pada dasarnya merupakan tugas dari pekerjaan media. Berbagai realitas yang terjadi di lapangan, kemudian dihimpun dan dipilih mana yang akan dikonstruksi dan mana yang akan dibuang. Maka dari itu, karena keampuhannya dalam mengkonstruksi realita, media mempunyai pengaruh yang besar untuk memberikan makna juga gambaran bagi masyarakat akibat hasil konstruksinya. Bahkan, meskipun pada dasarnya tujuan awal media adalah melaporkan atau menyampaikan informasi, namun tidak dapat dipungkiri bahwa dibalik pemilihan kata, istilah, atau simbol yang tertera, akan mengandung makna tertentu di masyarakat.(Sobur, 2012)

Sehingga, apapun yang disampaikan berita oleh media dari wartawan, memiliki beberapa penilaian yang dapat dilihat sebagai suatu konstruksi realitas, diantaranya:

1. Fakta/ atau peristiwa adalah hasil konstruksi

2. Media adalah agen konstruksi

3. Suatu berita bukan merupakan bagian dari refleksi realitas, melainkan bagian dari konstruksi realitas

4. Sifat berita subyektif

5. Seorang wartawan merupakan salah seorang agen konstruksi realitas

6. Etika, pilihan moral, dan keberpihakan wartawan merupakan komposisi dalam memproduksi suatu berita.

7. Khalayak mempunyai penafsiran masing-masing dalam membaca berita.(Eriyanto, 2009) 
Setelah memahami konsep media, pers, jurnalisme, dan surat kabar, konsep konstruksi sosial menjadi salah satu konsep kesatuan yang tergabung didalamnya. Karena, luaran yang ingin diketahui melalui konsep ini yaitu perihal bagaimana media melalui produk jurnalismenya yang dituangkan kedalam suatu surat kabar mengkonstruksi suatu realita yang diperoleh di lapangan kedalam suatu pemberitaan hingga mempengaruhi suatu kebijakan pemerintah.

Kekuatan media yang disampaikan melalui pemberitaan tidak dapat dipungkiri mampu mempengaruhi terhadap suatu sistem politik, khususnya kedalam suatu kebijakan publik. Kemampuan media dalam hal penyusunan agenda, framing pemberitaan, hingga pembentukan opini publik dapat mempengaruhi persepsi publik juga sikap terhadap isu-isu politik. Tidak heran, semakin besar perhatian yang diberikan kepada isu, semakin besar pula publik menganggapnya sebagai agenda penting. (Parsons, 2014)

Bahkan, menurut Robinson melalui teori policy media interaction dalam buku Media dan Politik yang ditulis oleh Salvatore Simarmata menyatakan, pengaruh media terhadap suatu kebijakan publik terjadi karena adanya ketidakpastian kebijakan diiringi dengan munculnya berbagai macam pertentangan di lapangan dan antarelit dalam mensikapi suatu masalah. Pada kondisi ini, jurnalis mampu membingkai pemberitaan atas kritik ketidakpedulian pemerintah sebagai salah satu bentuk tekanan politik agar pemerintah segera bertindak. Dengan demikian, media tidak dapat dipungkiri berorientasi untuk mempengaruhi suatu kebijakan.(Simarmata, 2014)

Penggunaan konsep kebijakan publik pada penelitian ini dimaksudkan untuk mengetahui sejauh mana upaya yang dilakukan media untuk memperhatikan dan mengevaluasi kembali kebijakan perihal PKL yang telah diimplementasikan. Melalui kebijakan publik pula, dapat terlihat posisi media untuk memasuki suatu sistem politik, termasuk elemen-elemen didalamnya.

Atas latar belakang diatas, penulis kiranya tertarik untuk meneliti lebih lanjut terkait bingkai berita yang dilakukan HU Kabar Priangan pada pemberitaan PKL Cihideung periode April - September 2017 upaya mendesak dan mempengaruhi regulasi/ atau kebijakan pemerintah terkait PKL.

\section{METODOLOGI PENELITIAN}

Metode penelitian yang digunakan pada penelitian ini adalah metode penelitian kualitatif interpretatif dengan paradigma konstruksifisme. Beberapa teknik yang dilakukan untuk mengumpulkan data pada penelitian ini diantaranya dengan membaca empat naskah berita dan menganalisisnya dengan menggunakan pendekatan yang sudah ditentukan yang berasal dari kajian dokumen (berita) dan wawancara, diantaranya

1. Edisi 10 April 2017, berita PKL dengan judul "Cihideung Semrawut, Kotor, dan Kumuh"

2. Edisi 10 April 2017, berita PKL dengan judul "Para Pedagang Menolak Direlokasi, Tertibkan Cihideung Pemkot Siapkan Sejumlah Opsi"

3. Edisi 21 Juli 2017, berita PKL dengan judul "Komisi II DPRD, Minta Wali Kota Segera Tertibkan Kawasan Cihideung" 
4. Edisi 7 September 2017, berita PKL dengan judul "PKL Cihideung Sudah Menyalahi Konsep Awal"

Selain itu, penelitian ini pula dianalisis menggunakan model framing Robert $\mathrm{N}$ Entman yang didukung dengan tiga validitas data, yaitu interpretasi penulis, telaah pustaka, dan wawancara.

Tabel 1.1 Klasifikasi Framing Robert N. Entman

\begin{tabular}{|c|c|}
\hline $\begin{array}{l}\text { Pendefinisian masalah } \\
\text { (Define problems) }\end{array}$ & $\begin{array}{l}\text { Bagaimana suatu peristiwa/ atau isu } \\
\text { dilihat? } \\
\text { Sebagai apa? } \\
\text { Atau sebagai masalah apa? }\end{array}$ \\
\hline $\begin{array}{l}\text { Memperkirakan masalah atau } \\
\text { sumber masalah } \\
\text { (Diagnose cause) }\end{array}$ & $\begin{array}{l}\text { Peristiwa itu dilihat disebabkan oleh apa? } \\
\text { Apa yang dianggap sebagai penyebab dari } \\
\text { suatu masalah? } \\
\text { Siapa aktor yang dianggap sebagai } \\
\text { penyebab masalah? }\end{array}$ \\
\hline $\begin{array}{l}\text { Membuat moral keputusan } \\
\text { (Make moral judgement) }\end{array}$ & $\begin{array}{l}\text { Nilai moral apa yang disajikan untuk } \\
\text { menjelaskan masalah? } \\
\text { Nilai moral apa yang dipakai untuk } \\
\text { melegitimasi atau mendelegitimasi suatu } \\
\text { tindakan? }\end{array}$ \\
\hline $\begin{array}{l}\text { Menekankan penyelesaian } \\
\text { (Treatment recommendation) }\end{array}$ & $\begin{array}{l}\text { Penyelesaian apa yang ditawarkan untuk } \\
\text { mengatasi masalah/isu? } \\
\text { Jalan apa yang ditawarkan dan harus } \\
\text { ditempuh untuk mengatasi masalah? }\end{array}$ \\
\hline
\end{tabular}

Sumber: Eriyanto. (2009). Analisis Framing Konstruksi, Ideologi, dan Politik Media. Yogyakarta: PT LKiS Printing Cemerlang. Hal 188-189.

\section{HASIL DAN PEMBAHASAN}

Surat kabar Harian Umum Kabar Priangan merupakan salah satu koran lokal yang berada di Kota Tasikmalaya dibawah naungan PT Berkah Pikiran Rakyat (Grup Pikiran Rakyat) dengan tagline "Terbaik dan Berpengaruh". Surat kabar ini berdiri dengan SIUPP No. 758/SK/Menpen. SIUPP/1998, 4 Desember 1998 dengan SK ISSN 0005.2527550X/Jl.3.1/SK.ISSN/2016.05, 25 Mei 2016. Kantor redaksinya berada di Jalan R.E Martadinata No 215 A Kota Tasikmalaya.

Dengan terbit setiap hari, surat kabar HU Kabar Priangan terbit dengan beberapa rubrikasi harian dan mingguan. Pada setiap daerah di wilayah Priangan Timur, diberikan satu kolom dan dijadikan rubrikasi pemberitaan pada setiap harinya, diantaranya Kabar Kota Tasik, Kab Tasik, Sumedang, Banjar, Ciamis, Pangandaran, dan Garut. Selain itu, beberapa rubrikasi lain upaya menunjang berbagai aspek pun turut dibentuk, seperti Saba Kampus, Saba Desa, Saba Sakola, dan Saba Pasantren. Keempat rubrik tersebut, khusus membahas perihal satu hal tertentu dan terbit satu minggu satu kali secara berkala. Bahkan pada rubrik khusus tersebut, HU Kabar Priangan tidak hanya menerbitkan tulisan/informasi yang berasal 
dari jurnalis HU Kabar Priangan itu sendiri, melainkan menerima berbagai macam tulisan yang sesuai dengan rubrik dari masyarakat luas.

Selain rubrik khusus, ada pula rubrik yang hadir lainnya seperti Kabar Bisnis yang fokus memberitakan perihal perkembangan ekonomi dan bisnis, Keluarga yang fokus memberitakan berbagai informasi perihal rumah tangga, Opini yang memuat berbagai ide dan gagasan dari masyarakat luas, Pendidikan, Kabar Pilkada, Kiprah, Kalang, Bidik, Nyalse, Budaya, dan Ragam Iklam.

Media, khususnya HU Kabar Priangan yang berperan sebagai wadah penafsir isu diupayakan mampu menganalisis berita ataupun isu yang sedang terjadi. Hal tersebut karena peran media disamping menginformasikan, juga berperan sebagai pengkritik pemerintah (watchdog). Melalui watchdog tersebut, media menyajikan informasi yang kredibel (bukan hoax) namun dibingkai (framing) sedemikian rupa agar menarik perhatian stakeholder yang turut serta menyelesaikan permasalahan tersebut.(Ishwara, 2016)

Dari hasil literature review pemberitaan yang hadir, Harian Umum Kabar Priangan terhitung empat kali memberitakan PKL Cihideung. Dari keempat berita tersebut, tiga berita ditempatkan di halaman awal, sedangkan satu berita lagi ditempatkan di halaman dua kolom Kota Tasikmalaya. Dalam artian, suatu berita ditempatkan di halaman awal menandakan bahwa berita tersebut bernilai sangat penting, agar mudah terbaca/ atau diingat oleh pembaca, juga sebagai bentuk penekanan/penonjolan berita pada hari tersebut.

Maka dari itu, berita PKL Cihideung dinilai penting bagi media karena memiliki nilai-nilai berita yang sesuai dengan kategorinya, seperti nilai akibat (impact), aktual (timeliness), hingga konflik (conflict).(Nur Amaliyah, 2016 ) Suatu berita dinilai memiliki akibat yang mempengaruhi orang banyak, maka layak menjadi suatu berita. Kemudian, suatu berita dinilai memiliki aktual karena aset utama dari berita yaitu kesegaran (freshness) yang menentukan apakah layak dihimpun ataupun di jual. Juga suatu berita dinilai memiliki konflik ketika suatu isu sudah banyak diperdebatkan ataupun membuat berbagai pihak geram. Berbagai konflik pro dan kontra hingga konflik pencemaran lingkungan yang menjadi dampak, merupakan layak untuk dijadikan berita.( Ishwara, 2016)

Sehingga pada penerapannya, framing dibuat untuk menghasilkan beberapa efek seperti menggiring opini publik dan menggiring publik pada satu aspek/ingatan tertentu. Berkaitan dengan polemik PKL Cihideung, HU Kabar Priangan membingkai keempat berita untuk memberikan pemahaman berbeda terhadap polemik tersebut. Upaya itu dilakukan melalui bagaimana suatu polemik dikemas, dipahami, dan didefinisikan. Sehingga dalam pembingkaiannya, ada aspek yang ditonjolkan, ada pula yang dikaburkan. Ada aspek yang ditampilkan, ada pula yang tidak ditampilkan. Juga ada aktor yang ditampilkan, ada pula yang disembunyikan. (Eriyanto,2015) Bahkan, jauh lebih dalamnya lagi, framing dibuat sebagai salah satu bentuk watchdog media. Melalui bingkai pemberitaan atas makna yang dipahaminya, media pun mengkritik atas apa yang dimaknainya.

Melalui riset ini, penulis mengkaji keempat pemberitaan PKL yang diterbitkan oleh HU Kabar Priangan dengan menggunakan konsep analisis framing Robert N. Entman dengan kriteria pendefinisian masalah (define problems), memperkirakan masalah atau sumber masalah (diagnose cause), membuat moral keputusan (make moral judgement), dan menekankan penyelesaian (treatment recommendation). 


\section{Cihideung Semrawut, Kotor, dan Kumuh (Edisi Senin, 10 April 2017) Pendefinisian Masalah (Define Problems)}

Pada berita ini, PKL dilihat sebagai sumber masalah utama yang menimbulkan permasalahan-permasalahan baru terhadap yang lainnya. Permasalahan tersebut kemudian diperjelas dengan keluhan-keluhan pedagang yang menempati rumah toko yang membandingkan keadaan PKL Cihideung dulu dengan sekarang, pejalan kaki, dan petugas parkir.

Ketiga narasumber yang dibingkai oleh HU Kabar Priangan tersebut merepresentasikan bahwa PKL dianggap mengganggu stabilitas ekonomi lainnya. Diawali oleh seorang pejalan kaki yang merasa terganggu karena trotoar yang seharusnya digunakan dan merupakan hak pejalan kaki, kini direbut oleh PKL. Trotoar hanya menyisakan sedikit jalan yang hanya mampu dilalui oleh satu orang. Sehingga, jika ingin bepergian melewati Cihideung harus senantiasa berhimpitan dengan para PKL.

Disamping itu, banyaknya pedagang rumah toko etnis Tionghoa yang terhalang oleh kios-kios PKL dibingkai secara representatif mengingat hampir sepanjang jalan Cihideung rumah toko tersebut dimiliki oleh sejumlah etnis Tioghoa. Pengambilan narasumber pedagang rumah toko tersebut dikarenakan PKL memang memiliki dampak negatif bagi keberlangsungan ekonomi pedagang yang menempati rumah toko. Deretan kios-kios PKL menutupi rumah-rumah toko hingga tidak terlihat.

Bahkan jika dilihat lebih dalam, pengambilan narasumber pedagang rumah toko yang mayoritas etnis Tionghoa tersebut menafsirkan bahwa etnis Tionghoa yang merupakan kaum minoritas di Kota Tasikmalaya terkesan disingkirkan. Rumah-rumah toko yang tertutup kioskios PKL seolah menandakan pemerintah tidak mampu mendengarkan juga menampung aspirasi kaum minoritas untuk berdagang di Kota Tasikmalaya. Pemerintah dirasa tidak adil dan tidak tegas dalam membuat konsep juga regulasi PKL Cihideung yang merugikan banyak pihak termasuk pedagang rumah toko.

Akan tetapi, pada berita ini HU Kabar Priangan membingkainya dengan menghadirkan salah seorang pedagang rumah toko yang terdampak oleh PKL Cihideung. Pembingkaian ini dilakukan sebagai upaya HU Kabar Priangan menyeimbangkan dampak yang ditimbulkan PKL selain ke pejalan kaki dan petugas parkir.

Elemen terakhir yang memiliki dampak besar setelah trotoar dan pedagang yang menempati rumah toko yaitu petugas parkir. Penulis melihat, bingkai berita pada elemen ini seolah menandakan bahwa parkir di bahu jalan diperbolehkan. Pengambilan narasumber petugas parkir yang mengatakan bahwa pendapatannya menurun menafsirkan bahwa keberlangsungan parkir di bahu jalan bukan merupakan masalah. Padahal, hemat penulis jika dilihat lebih dalam, parkir menjadi salah satu elemen yang menyebabkan kondisi Cihideung semakin semrawut setelah PKL. Disepanjang jalan, parkir hampir sama dengan PKL memakan setengah badan jalan. Dampaknya, hak pengendara kendaraan pun terabaikan. Pengendara motor apalagi mobil harus berhimpitan melewati jalan dua jalur yang menjadi sempit karena parkir dan PKL. 
"Sejak akhir 2015, Jalan Cihideung menyempit. Laju arus lalu lintas di pusat perdagangan Kota Tasikmalaya ini pun menjadi tersendat. Adanya Pedagang Kaki Lima di sepanjang jalan dituding sebagai penyebab. Pasalnya sebelum ada lapak PKL yang menghabiskan setengah badan jalan, kemacetan di jalan ini tidak begitu semrawut seperti sekarang"

"Trotoar pun tak ada yang berubah. Ruang pejalan kaki masih terganggu oleh banyaknya pedagang...”

"Dulu mah teu kieu da parkir ge enakeun. Ayeuna mah kan kahalangan ku kios-kios. Jadi banyak pembeli tidak jadi datang karena papan toko saja terhalang sehingga calon pembeli kerap kebingungan, ujar pemilik toko Poantong, Ting-ting (60)",

"Ting ting pun semakin merasa tak nyaman berada di kawasan Cihideung karena lingkungan bukan tambah membaik melainkan semakin sareukseuk. Malah kalau malam hari terkadang bau pesing. Ketika hujan semakin becek, karena air hujan jatuh dari atap atap kaki lima”

"Tak hanya pedagang di ruko, petugas parkir yang terdiri dari 24 orang merasakan, pendapatan menurun karena jumlah kendaraan yang parkir berkurang dan pindah ke Mayasari Plasa. Sejak adanya lapak kaki lima yang mengakibatkan penyempitan jalan, sedikit sekali yang mau parkir di Cihideung” (Harian Umum Kabar Priangan edisi Senin, 10 April 2017)

Bahkan, pada berita ini pula diangkat kembali beberapa permasalahan PKL Cihideung dibawah beberapa pimpinan Wali Kota terdahulu. Melalui pengangkatan kondisi terdahulu PKL Cihideung, HU Kabar Priangan mengkosntruksi bahwa persoalan PKL Cihideung sejak dari dulu seolah tidak mempunyai solusi yang tepat hingga saat ini.

"Menjamurnya kaki lima Cihideung sudah ada sejak 1982 di era Wali Kota Administratif, Iyeng Prawiranegara dengan Bupati Tasikmalaya, Adang Rusman. Pedagang menempati trotoar Cihideung karena berdekatan dengan Pasar Resik yang kini menjadi Mayasari Plasa”

"Pernah pula ada relokasi sekira tahun 1993an jaman Bupati, Adang Rusman. Pedagang Cihideung ditempatkan ke jalan Selakaso, namun tetap mereka kembali lagi ke Cihideung. Termasuk mereka juga sempat direlokasi ke Pasar Cikurubuk, dan akhirnya kembali lagi ke Cihideung dengan alasan sepi"

Melalui penjelasan awal mula PKL Cihideung pula, HU Kabar Priangan membingkai serangkaian polemik PKL yang mengganggu fasilitas publik lainnya dari tahun 1982 hingga 2011. Bahkan, para PKL pernah dibawa studi banding ke Pasar Cicadas Bandung oleh 
pemerintah kota, namun tetap saja PKL Cihideung tidak teratur dan mengganggu fasilitas publik lainnya. Hingga akhirnya, pasca studi banding tersebut, pemerintah kurang memperhatikan kembali penataan PKL.

\section{Memperkirakan Masalah atau Sumber Masalah (Diagnose Causes)}

Perkiraan penyebab masalah pada polemik PKL Cihideung ini yaitu pemerintah Kota Tasikmalaya. Meski dalam pemberitaan tidak menyebutkan bahwa pemerintah merupakan aktor yang salah, akan tetapi melalui pembingkaiannya yang terlihat dari awal mula serta narasumber yang diwawancara, jelas berita ini mengarah pada pemerintah.

Pemerintah dinilai bersalah pada konteks ini dikarenakan ketidakmampuannya dalam menata PKL Cihideung hingga menimbulkan kesemrawutan, kumuh, dan kotor. Para PKL tentu tidak akan berjualan disana, jika aturan juga pengimplementasian peraturan daerah yang berlaku ditegakkan dengan baik dan benar.

“...Namun menurutnya, kondisi ini tidak bisa menyalahkan pedagang kaki lima saja, tapi Pemerintah Kota Tasikmalaya juga harus mawas diri”

"Da pamarentah nu kawasa. Bade kumaha abdi mah moal tiasa naon-naon" "Contohnya, kata dia, roda yang diberikan oleh Pemkot Tasikmalaya tidak sesuai peruntukannya. Dia mengatakan, mayoritas pedagang kaki lima Cihideung ini lebih banyak yang menjual barang, bukan makanan. Tapi pemerintah justru menyediakan gerobak makanan"

“...Adanya bantuan roda dari Pemkot Tasikmalaya hanya menguntungkan pedagang kuliner saja...”

"Karena tidak berembuk dulu soal bentuk lapak. Roda yang berjajar banyak yang diubah dan tidak terpakai karena harus menyesuaikan jenis barang jualan...” (Harian Umum Kabar Priangan edisi Senin, 10 April 2017)

Melalui pemberitaan ini pula, pemerintah disudutkan dengan bantuan gerobak yang diberikan kepada PKL Cihideung namun tidak sesuai peruntukannya. Secara implisit, hal tersebut semakin menonjolkan ketidakmampuan pemerintah dalam menata dan mengelola PKL Cihideung. Disamping itu, penulis melihat, inkonsistensi pemerintah Kota dalam memberikan bantuan gerobak tersebut berbenturan dengan perda yang melarang PKL berjualan di fasilitas publik yang telah ditentukan.

Sehingga di satu sisi, pemerintah memberikan bantuan gerobak memberikan kesan bahwa berdagang di bahu jalan hingga trotoar adalah legal. Akan tetapi, jika dilihat pada perda Kota Tasikmalaya nomor 2 tahun 2009 tentang Perubahan Atas Peraturan Daerah Kota Tasikmalaya Nomor 28 Tahun 2003 Tentang Pengelolaan Pasar di Kota Tasikmalaya pasal $7 \mathrm{E}$ ayat $2 \mathrm{C}$ menegaskan bahwa pemerintah melarang untuk berdagang pada jatah ruang yang telah disepakati serta tidak mengambil lahan/ruang yang telah diperuntukkan untuk kepentingan lain, seperti jalan, taman, dan trotoar. 


\section{Membuat Keputusan Moral (Make Moral Judgement)}

Berdasarkan define problems dan diagnose causes diatas, berita PKL pada edisi ini diperkuat dan dibingkai dengan pernyataan bahwa kondisi PKL Cihideung saat ini bukan merupakan rekomendasi alternatif belanja. PKL Cihideung pada saat ini telah membuat calon pembeli tidak merasa nyaman, sehingga para pembeli lebih memilih untuk berbelanja ke tempat lain daripada di kawasan PKL Cihideung.

"Dulu mah kalau kita perlu sesuatu, solusi yang paling tepat adalah Cihideung. Sebelum kemana-mana, kita ke Cihideung dulu karena di kawasan itu segala ada dan harganya pun masuk akal, kata Ny. Ina, warga Kota Tasikmalaya”( Harian Umum Kabar Priangan edisi Senin, 10 April 2017)

"Namun sekarang, kata dia, daripada ke Cihideung mendingan ke tempat lain karena sareukseuk dan benar-benar tak nyaman"

"Daripada ka Cihideung mah, mendingan ka tempat lain we bade balanja mah. Nya sareukseuk, tukang becak sangeunahna, jeung hese parkir deui" (Harian Umum Kabar Priangan edisi Senin, 10 April 2017)

Maka dari itu, melalui hasil wawancara narasumber yang merupakan warga Kota Tasikmalaya tersebut, HU Kabar Priangan membingkai dan mengutipnya sebagai argumentasi pendukung untuk memperkuat. Hal ini pula, menafsirkan bahwa pemerintah tidak mampu menjadikan kawasan PKL Cihideung sebagai alternatif tempat belanja juga pemberdayaan Usaha Mikro Kecil Menengah (UMKM). Hemat penulis, jika pemerintah mampu menata PKL Cihideung dengan baik, maka secara tidak langsung pemerintah pun memberdayakan PKL. Selain itu, masyarakat nantinya mampu menilai juga membandingkan hingga menjadikan alternatif belanja berbagai macam kebutuhan ditengah daya saing ekonomi di kawasan pertokoan Cihideung.

\section{Menekankan Penyelesaian (Treatment Recommendation)}

Pada berita edisi ini, HU Kabar Priangan memberikan penyelesaian secara terpisah. Dalam artian, HU Kabar Priangan melakukan beberapa klarifikasi dengan mewawancara beberapa narasumber terkait untuk mencari penyelesaian akan tetapi penyelesaian tersebut ditulis terpisah namun masih satu kesatuan dengan berita edisi ini dengan hari terbit yang sama.

\section{Tertibkan Cihideung, Pemkot Siapkan Sejumlah Opsi (Edisi Senin, 10 April 2017) Pendefinisian Masalah (Define Problems)}

Pada berita edisi ini, HU Kabar Priangan melihat PKL Cihideung yang sulit untuk direlokasi oleh pemerintah. Penulis melihat, pemerintah belum menemukan peraturan yang win win solution yang mampu bersifat adil dan sejahtera bagi berbagai pihak sehingga tidak ada yang dirugikan. Pada edisi ini pula, pemerintah terkesan tidak mampu dalam menata PKL melalui solusi-solusi yang ditawarkannya. 
“...Muncul selentingan bahwa lapak kaki lima memuka akan direlokasi. Akan tetapi pedagang minta rencana tersebut ditunda karena akan menghadapi marema..."

"Kalau relokasi mah kami tidak setuju karena kami disini sudah turun temurun dari kakek kami. Kemana lagi harus berjualan kalau lapak kami dipindah..."

“...Pernah ada pihak Indag datang ke mereka menyampaikan penertiban pedagang di trotoar. Tapi sangat sulit karena ada juga pedagang yang nakal dengan alasan di lapak kaki lama tidak laku” (Harian Umum Kabar Priangan edisi Senin, 10 April 2017)

Dari beberapa kutipan diatas, HU Kabar Priangan membingkai beberapa penolakan para PKL untuk direlokasi dikarenakan berbagai alasan. Pada hal ini, kutipan diatas digunakan HU Kabar Priangan upaya menonjolkan ketidak mampuan pemerintah dalam menata juga memberikan win win solution bagi para PKL.

\section{Memperkirakan Penyebab Masalah (Diagnose Causes)}

Pada berita edisi ini, perkiraan penyebab masalah dibingkai untuk tertuju pada pemerintah. Dengan membangun realitas kegagalan pemerintah dalam merelokasi PKL, mengatasi pedagang yang nakal, hingga penolakan, realitas tersebut menjadi fakta yang dibangun bahwa pemkot tidak berdaya. Akan tetapi, upaya memenuhi berita cover both side, HU Kabar Priangan memberikan space khusus untuk mengklarifikasi dengan mewawancara pihak-pihak terkait pada berita edisi ini.

Sehingga, kesan pemerintah yang tidak mampu mengatasi polemik PKL Cihideung perlahan berkurang hingga menimbulkan kesan positif bahwasannya pemerintah berfikir dan bergerak untuk menata PKL Cihideung menjadi semakin kondusif.

\section{"Sementara itu, Pemerintah Kota Tasikmalaya telah menyiapkan beberapa wacana alternatif terkait dengan penataan PKL Cihideung... "(Harian Umum Kabar Priangan edisi Senin, 10 April 2017)}

Melihat hal diatas, HU Kabar Priangan pada edisi ini menempatkan posisinya sebagai partisipan yang menjembatani keragaman subjektifitas pelaku sosial. Dalam artian, dari banyaknya subjektifitas melalui kutipan dan pernyataan, HU Kabar Priangan pun berperan sebagai intermediator antara PKL dengan pemerintah dalam menciptakan kondusifitas

\section{Membuat Keputusan Moral (Make Moral Judgement)}

Pada judul kecil yang ditulis di awal "para pedagang menolak di relokasi”, dibingkai untuk menafsirkan bahwa PKL tidak keberatan untuk ditata namun tidak dengan cara relokasi. Setelah judul kecil tersebut, judul besar "Tertibkan Cihideung, Pemkot Siapkan 
Sejumlah Opsi” mengandung makna bahwa PKL senantiasa harus memilih beberapa pilihan yang disiapkan pemkot.

"Kalau hanya menata agar tidak kumuh sedang kami usahakan. Terpenting jangan di relokasi, katanya")(Harian Umum Kabar Priangan edisi Senin, 10 April 2017)

Kutipan diatas menjadi argumentasi pendukung untuk memperkuat soal kesiapan penataan para PKL.

\section{Menekankan Penyelesaian (Treatment Recommendation)}

Terdapat dua narasumber terkait yang mengatasnamakan pemkot upaya melakukan penataan PKL Cihideung, yaitu Kepala Dinas Koperindag Kota Tasikmalaya Tantan Rustandi dan Plt Kepala Dinas Satpol PP Kota Tasikmalaya Asep MP. Pernyataan keduanya menandakan bahwa kesiapan pemerintah dalam melakukan penataan PKL Cihideung dari mulai perencanaan hingga pembinaan.

"Pada prinsipnya perlu ada jalan tengah antara keinginan pedagang dengan keinginan masyarakat..."

"Opsi tersebut, kata dia, mulai dari batas operasional hingga penataan lebih ke arah estetika. Sebab kondisi saat ini sangat kumuh dan tidak nyaman bagi pedagang serta masyarakat"

“...Pemkot tentunya ingin konsep yang matang supaya tidak capai dua kali. Jadi bisa seterusnya, tidak sedikit-sedikit berubah lagi...”

“...Kalau memang ketidaksesuaian dengan apa yang diprogramkan pemerintah, baru kita lakukan penindakan...”

“...Kalau yang sudah menyalahi program baru kita tindak...”(Harian Umum Kabar Priangan edisi Senin, 10 April 2017)

Kutipan-kutipan diatas, menjadi salah satu upaya penyelesaian yang dibingkai oleh HU Kabar Priangan berdasarkan realitas wawancara narasumber. Penetapan narasumbernarasumber tersebut menjadi penghubung yang tepat untuk menemukan titik temu antara keinginan PKL juga penataan pemerintah.

Meskipun demikian, hemat penulis, penekanan penataan PKL disini tetap harus menghasilkan keputusan yang win-win solution. Pemerintah harus benar-benar mengkaji kondisi PKL Cihideung sebelum benar-benar diberlakukan kedalam suatu aturan atau perda. Maka dari itu, melalui berita pada edisi ini, treatment recommendation secara implisit ditujukan bagi sekelompok PKL Cihideung untuk dijadikan gambaran agar keinginan antara PKL juga pemerintah bisa terakomodir. Sehingga capaian yang diharapkan yaitu PKL Cihideung tidak lagi semrawut, kotor, dan kumuh, sesuai dengan perda yang telah ditentukan 
juga disepakati bersama. Untuk mencapai itu semua, melalui pemberitaan Liputan Khusus ini, HU Kabar Priangan mengajak musyawarah antara pihak-pihak terkait khususnya PKL dan pemerintah dalam membuat kebijakan yang win win solution.

\section{Komisi 2 DPRD, Minta Wali Kota Segera Tertibkan Kawasan Cihideung (Edisi Jumat,} 21 Juli 2017)

\section{Pendefinisian Masalah (Define Problems)}

Polemik PKL Cihideung pada berita edisi ini dilihat sebagai suatu permasalahan yang masih belum tertangani oleh pemerintah. Padahal, Wali Kota sebelumnya sudah berjanji akan menertibkan PKL setelah lebaran. Akan tetapi, janjinya tersebut belum direalisasikan. Secara fundamental, polemik PKL Cihideung merupakan permasalahan yang berada di sektor fasilitas publik. Sedang fasilitas publik, sudah tentu tidak digunakan oleh perorangan atau sekelompok orang, melainkan seluruh masyarakat mampu menggunakan juga mendapatkan haknya masing-masing.

Karena berada di sektor fasilitas publik tersebut, PKL Cihideung dinilai penting dan mendesak untuk segera ditangani. Pada berita ini, Wali Kota dibingkai dengan kesan bahwa pemkot abai terhadap fasilitas juga hak publik lainnya untuk menggunakan fasilitas publik.

\footnotetext{
"Sebelumnya, Wali Kota Tasikmalaya, berjanji setelah lebaran akan menertibkan PKL di kawasan Cihideung. Hanya hingga kini belum direalisasikan” (Harian Umum Kabar Priangan edisi Jumat, 21 Juli 2017, kolom Kota Tasikmalaya)
}

Ditambah, jangka waktu yang sudah cukup lama dan berlarut, membuat polemik PKL Cihideung ini tak kunjung usai dan tertangani. Jika dilihat lebih dalam, HU Kabar Priangan membingkai janji yang disampaikan oleh Wali Kota sebagai aspek yang ditonjolkan. Terlebih sebagai seorang tokoh pejabat, pembicaraan apapun dalam bentuk verbal maupun tertulis akan terus dipantau dan dikritisi oleh suatu media.

\section{Memperkirakan Penyebab Masalah (Diagnose Causes)}

Polemik PKL Cihideung yang belum ditangani oleh pihak pemerintah, semakin hari semakin memprihatinkan. HU Kabar Priangan membingkai berita ini dengan melihat realitas perkembangan PKL Cihideung yang semakin hari semakin tidak nyaman. Atas realitas yang belum tertangani tersebut, penggiringan objek penyebab masalah jelas ditujukan kepada pemerintah yang ditekankan oleh janji yang belum terealisasikan oleh Wali Kota di atas.

\footnotetext{
"Kawasan Cihideung kian hari kondisinya makin memprihatinkan. Selain makin sesak juga terkesan kumuh. Para PKL juga banyak memasang tenda permanen sehingga makin membuat tidak nyaman. Belum lagi jika turun hujan akan terjadi genangan air sehingga menghambat arus lalu lintas" (Harian Umum Kabar Priangan edisi Jumat, 21 Juli 2017, kolom Kota Tasikmalaya)
} 
Pada berita ini, terlihat HU Kabar Priangan tidak hanya menjadi watchdog berdasarkan keluhan-keluhan yang diperoleh dari narasumber, akan tetapi dilihat pula berdasarkan realitas di lapangan. Sehingga pada berita ini, bingkai media yang dilakukan HU Kabar Priangan menggambarkan fakta (bukan hoax) namun digiring dengan bingkai yang ingin dimaksud oleh HU Kabar Priangan. Jika dilihat dari berita pertama hingga yang ketiga ini, pada setiap pemberitaan PKL Cihideung, HU Kabar Priangan sering kali menggunakan kata-kata yang bermakna sedang membutuhkan pertolongan, seperti kumuh, kotor, dan semrawut. Pada berita ini, HU Kabar Priangan kembali menggunakan kata bermakna kesan belas kasihan, yaitu prihatin.

Dalam Kamus Besar Bahasa Indonesia, prihatin merupakan bersedih hati, was-was, bimbang (karena usahanya gagal, mendapat kesulitan, mengingat akan nasibnya, dsb) (edisi Jumat, 21 Juli 2017) kolom Kota Tasikmalaya. Pada posisi ini, melalui pemberitaannya, HU Kabar Priangan mengungkapkan rasa yang dilihatnya sekaligus menjadi kritik bagi pemerintah dengan menggunakan kata prihatin melihat keadaan PKL Cihideung hingga saat ini. Maka sesuai dengan maknanya, penggunaan kata prihatin oleh HU Kabar Priangan secara mendalam menginterpretasikan betapa sulit dan jatuh bangunnya pemerintah dalam menata para PKL Cihideung. Ditambah, penekanan bahwasannya kawasan PKL Cihideung sudah semakin tidak nyaman, kembali dibangun dan dikutip oleh HU Kabar Priangan melalui wawancara dua narasumber, yaitu warga Cieunteung dan pegawai toko di Cihideung.

\title{
Membuat Pilihan Moral (Make Moral Judgement)
}

Argumentasi pendukung pada berita ini, HU Kabar Priangan menggandeng Ketua dan Sekretaris Komisi II DPRD Kota Tasikmalaya untuk mengklarifikasi yang juga merasakan hal yang sama bahwasannya kondisi PKL Cihideung saat ini tidak nyaman.

\begin{abstract}
"Ketua Komisi II DPRD Kota Tasikmalaya, Ichwan Safa menuturkan rencana penataan kawasan Cihideung harus segera dilakukan. Sebab kawasan Cihideung tidak hanya jadi etalase Kota Tasikmalaya, tapi juga jadi etalase para PKL di Kota Tasikmalaya. Bila terus dibiarkan, akan dijadikan alasan oleh PKL di luar Cihideung untuk berdagang di sembarang tempat"
\end{abstract}

\begin{abstract}
"Sekretaris Komisi II DPRD Kota Tasikmalaya, Andi Warsandi menuturkan isu-isu penataan Cihideung yang dijanjikan Wali Kota diharapkan dapat segera direalisasikan mengingat penuh sesaknya kawasan Cihideung sudah banyak dikeluhkan masyarakat. Adanya lapak permanen dari para PKL tidak selaras dengan estetika penataan Kota Tasik. Diperparah dengan kondisi parkir kendaraan roda dua yang memakan bahu jalan, sehingga menyebabkan kemacetan” (Harian Umum Kabar Priangan edisi Jumat, 21 Juli 2017, kolom Kota Tasikmalaya)
\end{abstract}

Maka secara tidak langsung, bingkai media yang dilakukan HU Kabar Priangan dengan menyertakan narasumber dari legislatif yaitu untuk melegalkan argumentasi 
sekaligus mendorong pemerintah untuk segera menata PKL Cihideung. Bahkan, melalui pernyataan dari Ketua Komisi II jika dilihat lebih dalam, ia mengkhawatirkan jika kawasan PKL Cihideung dibiarkan seperti saat ini, akan mengundang PKL-PKL lain berdagang di kawasan Cihideung. Sehingga nantinya, PKL Cihideung akan semakin kumuh dan tidak nyaman.

Di satu sisi, bingkai media dengan menggunakan pernyataan dari legislatif ini mengisyaratkan bahwa PKL Cihideung kembali harus dikaji pada suatu sistem untuk menghasilkan kebijakan yang win-win solution. Karena, untuk mengatur polemik ini, salah satunya bisa diatur melalui peraturan atas kajian yang matang dan berkeadilan.

\section{Menekankan Penyelesaian (Treatment Recommendation)}

Sebagai bentuk saran, HU Kabar Priangan menekankan melalui pernyataan Ketua Komisi II DPRD Kota Tasikmalaya bahwasannya ada cara lain yang lebih strategis dan berkeadilan untuk menata PKL Cihideung selain dengan direlokasi.

"Penataan dan penertiban bukan berarti meniadakan. Artinya pemkot harus bisa menyiapkan langkah strategis tanpa meniadakan PKL"

“...Bisa dengan zonasi PKL sehingga tetap tertata dan para PKL tidak kehilangan mata pencahariannya” (Harian Umum Kabar Priangan edisi Jumat, 21 Juli 2017, kolom Kota Tasikmalaya)

Melalui kutipan diatas pula, HU Kabar Priangan memaknai dan menyarankan alternatif lain seperti zonasi PKL untuk menata tanpa harus merelokasi. Seperti yang diketahui sebelumnya, PKL Cihideung menolak direlokasi dikarenakan berbagai macam alasan. Maka, bingkai saran yang dibangun HU Kabar Priangan menjadi salah satu alternatif dalam menata PKL Cihideung.

\section{PKL Cihideung Sudah Menyalahi Konsep Awal (Edisi Kamis, 7 September 2017) Pendefinisian Masalah (Define Problems)}

Pada berita edisi ini, adanya PKL Cihideung yang menetap dan membuat permanen gerobak tersebut ternyata menyalahi kesepakatan yang sudah dibuat di awal antara pemerintah dan PKL Cihideung.

"Keberadaan 322 Pedagang Kaki Lima (PKL) gerobak yang berada di Jalan Cihideung Kota Tasikmalaya akan dievaluasi. Keberadaan PKL sekarang sudah tidak sesuai dengan konsep awal, yakni sistem buka tutup" (Harian Umum Kabar Priangan edisi Kamis, 7 September 2017)

Melalui berita ini, HU Kabar Priangan membingkai pernyataan diatas seolah pemerintah tidak melakukan pengawasan secara intensif pada kesepakatan tersebut. Melalui berita ini pula, HU Kabar Priangan menafsirkan inkonsistensi PKL terhadap kesepakatan yang sudah dibuat di awal. Idealnya, pihak pemerintah melakukan penegakan dari awal 
ditemukan ketidaksesuaian pada kesepakatan. Apabila dari awal sudah mampu ditindak diikuti dengan pembinaan secara persuasif, hemat penulis kondisi PKL Cihideung tidak akan menjadi seperti saat ini.

\section{Memperkirakan Penyebab Masalah (Diagnose Causes)}

Terdapat dua sisi yang diperkirakan menjadi penyebab masalah pada berita yang dibingkai HU Kabar Priangan ini. Pertama, inkonsistensi pedagang terhadap kesepakatan awal dengan pemerintah. Kedua, pemerintah yang abai terhadap pengawasan peraturan. Keduanya, dibingkai dengan cara dan penempatan yang berbeda. Dari pertama judul yang ditempatkan di awal, jelas jika dibaca sepintas pun pembaca pasti merasa kesal terhadap PKL Cihideung yang semakin semrawut sehingga menyebabkan penggiringan bahwa yang salah disini adalah PKL. Akan tetapi, jika dibaca dan dilihat secara keseluruhan, berita ini menjelaskan bahwa pemerintah abai terhadap pengawasan suatu kebijakan/aturan sehingga menimbulkan kekacauan seperti saat ini.

“...Keberadaan PKL Cihideung tidak sesuai dengan konsep awal. Sesuai dengan kesepakatan antara pemkot dengan para pedagang. PKL itu berdagang buka tutup. Para PKL selesai berjualan langsung membawa gerobaknya (roda) untuk dibawa pulang, sehingga kawasan Jalan Cihideung kembali bersih"

"Kondisi tersebut tentu menjadikan Jl Cihideung jadi semrawut dan kumuh dan menjadi sorotan semua pihak. Maka kami akan segera melakukan evaluasi” (Harian Umum Kabar Priangan edisi Kamis, 7 September 2017)

Pada pernyataan kedua, HU Kabar Priangan membingkai pemerintah yang lamban dalam menata PKL. Hal tersebut menandakan pemerintah bergerak ketika permasalahan sudah mengemuka hingga menimbulkan permasalahan-permasalahan baru. Pemerintah terkesan tidak cepat tanggap dalam memperhatikan kondisi PKL.

\section{Membuat Pilihan Moral (Make Moral Judgement)}

Argumentasi pendukung pada berita ini, HU Kabar Priangan mengutip pernyataan dari Kepala Bidang Perdagangan Disperindag Kota Tasikmalaya H. Uron yang semakin mengembangkan juga menonjolkan bahwa penataan PKL Cihideung oleh pemerintah hanya sebatas rencana dan rencana.

“...Evaluasi PKL Cihideung sedianya akan dilakukan setelah lebaran kemarin. Namun karena ada permohonan penundaan dari PKL, maka evaluasi ditunda hingga habis lebaran. Hanya sekarang terkendala dengan Tasik October Festival (TOF) HUT Kota Tasikmalaya, sehingga kemungkinan evaluasi akan dilakukan selesai kegiatan TOF” Harian Umum Kabar Priangan edisi Kamis, 7 September 2017 
Pernyataan diatas menjadi penekanan penjelasan argumentasi bahwa pemerintah terkesan mengesampingkan persoalan PKL Cihideung yang terus menerus ditunda karena adanya suatu acara. Ditambah, diakhir berita, pernyataan pemerintah yang mengatakan belum tahu bahkan belum ada perihal tempat relokasi (jika di relokasi), semakin memperlihatkan bahwa pemerintah belum begitu serius menangani kawasan PKL Cihideung.

\section{Menekankan Penyelesaian (Treatment Recommendation)}

\section{“...Evaluasi dilakukan dengan melakukan telaah dan beberapa kajian yang} mengacu kepada Raperda”

"...Nantinya setelah evaluasi juga akan membuat regulasi untuk wilayah Cihideung apakah daerah tersebut masuk zona hijau, kuning, atau merah"

\section{“...Zona hijau, wilayah yang bisa digunakan berjualan PKL. Kemudian zona kuning bisa dipakai berjualan, tapi secara buka tutup. Sedangkan zona merah, wilayah dilarang untuk berjualan PKL"( Harian Umum Kabar Priangan edisi Kamis, 7 September 2017)}

Pernyataan yang disampaikan oleh Kepala Bidang Perdagangan Disperindag tersebut dibingkai dan dikutip oleh HU Kabar Priangan dan dijadikan sebagai alternatif solusi upaya menata PKL Cihideung. HU Kabar Priangan membangun alternatif solusi tersebut dengan maksud agar dikaji dan ditinjau ulang kembali oleh pihak pemerintah agar menghasilkan kebijakan yang win-win solution. Suatu berita melalui bingkai yang telah dibangun oleh media, jelas akan berpengaruh bagi pembaca. Dapat terlihat dari pembuatan judul, penggunaan kalimat, serta penggunaan kutipan narasumber, sebagai beberapa indikator penonjolan berita. Sehingga, berdasarkan indikator tersebut akan tercipta suatu makna yang diingat dan dipahami oleh pembaca terhadap suatu peristiwa. Keempat berita PKL diatas merupakan hasil framing HU Kabar Priangan terhadap polemik PKL Cihideung yang hingga saat ini masih belum ditemukan solusinya oleh pemerintah. Keempatnya dibangun berdasarkan realitas di lapangan namun hanya aspek-aspek tertentu yang ditonjolkannya.

Maka hasil kajian yang diteliti penulis perihal polemik PKL Cihideung diatas adalah:

1. HU Kabar Priangan menempatkan penyajian keempat berita PKL Cihideung di halaman awal. Dalam artian, keempat berita tersebut dinilai penting, lebih menarik, lebih berarti, serta untuk lebih diingat oleh pembaca. Hal tersebut dengan sengaja ditempatkan di awal mengingat polemik PKL Cihideung berkaitan dengan kepentingan publik yang berdampak pada kepentingan publik lainnya.

2. Satu berita pada Senin, 10 April 2017 disajikan dalam Liputan Khusus perihal PKL Cihideung dengan ditempatkan di awal dan didukung foto keadaan. Pengangkatan berita dalam bentuk Liputan Khusus tersebut dinilai karena keadaan PKL Cihideung sudah kian semrawut, kotor, dan kumuh, akan tetapi tidak kunjung membaik. Ditambah, judul yang digunakan pada edisi ini secara implisit bermakna sedih dan 
membutuhkan pertolongan. Penulis melihat, interpretasi melalui judul amat sangat ditonjolkan oleh HU Kabar Priangan upaya menjadi pusat perhatian dan mempengaruhi pembaca luas.

3. Adapun bingkai yang dibuat oleh HU Kabar Priangan dari keempat berita diatas, penulis melihat bahwasannya polemik PKL dilihat sebagai masalah atas lemahnya pengawasan dan penindakan dari pemerintah. Padahal, dari awal mula kesepakatan antara PKL dengan pemerintah yaitu berdagang dengan buka tutup (setelah berjualan roda dibawa pulang). Akan tetapi, karena lemahnya pengawasan dan penindakan dari pemerintah, kesepakatan tersebut tidak berlaku hingga menyebabkan kesemrawutan yang membuat tidak nyaman

4. Dari keempat berita diatas, HU Kabar Priangan menempatkan PKL sebagai penyebab masalah secara kesepakatan, sedangkan pemerintah penyebab masalah secara peraturan. Keduanya dikritik melalui judul hingga kutipan-kutipan wawancara. Akan tetapi, penyebab masalah dominan yang dibingkai oleh HU Kabar Priangan berada di pihak pemerintah. Hal tersebut terlihat dari konsistensi pemberitaan yang selalu membahas keluhan-keluhan yang dirasakan oleh masyarakat hingga munculnya masalah baru seperti memakan hak pejalan kaki dan menutupi pedagang yang menempati rumah toko.

5. Perihal nilai moral yang dimuat, HU Kabar Priangan membingkainya dengan dukungan pernyataan pihak-pihak terkait untuk menonjolkan bahwasannya pemerintah lambat dalam menangani polemik PKL Cihideung ini.

6. Sehingga, solusi terakhir yang dibingkai HU Kabar Priangan untuk menata PKL Cihideung yaitu mengevaluasi peraturan daerah untuk dilakukan penataan yang melahirkan win-win solution, yaitu solusi yang saling menguntungkan, berkeadilan, serta tidak ada yang dirugikan antara satu dengan yang lainnya. Solusi ini dibingkai atas kutipan-kutipan pernyataan dari pihak-pihak terkait.

\section{PENUTUP}

Polemik PKL Cihideung yang hingga saat ini masih terus berlanjut menimbulkan berbagai pendapat serta kritik dari berbagai pihak. Keberadaannya dinilai mengganggu banyak pihak termasuk kepentingan publik. Tidak sedikit berbagai media massa dan online lokal Tasikmalaya mengkritik melalui pemberitaannya dengan beranekaragam framing. Salah satunya yaitu media Harian Umum Kabar Priangan.

Media yang berperan sebagai wadah penafsir isu diupayakan mampu menganalisis berita ataupun isu yang sedang terjadi. Hal tersebut karena peran media disamping menginformasikan, juga berperan sebagai pengkritik pemerintah (watchdog). Melalui watchdog tersebut, media menyajikan informasi yang kredibel (bukan hoax) namun dibingkai (framing) sedemikian rupa agar menarik perhatian stakeholder yang turut serta menyelesaikan permasalahan tersebut.

Hasil pengamatan penulis, HU Kabar Priangan mengkritik pemerintah kedalam empat berita selama tahun 2017, diantaranya pada 10 April, 21 Juli, dan 7 September. Keempat berita tersebut merupakan hasil bingkai juga kontruksi HU Kabar Priangan terhadap realitas yang terjadi terhadap PKL Cihideung. 
Penulis pun menyarankan kepada HU Kabar Priangan untuk menambahkan foto pendukung pada beberapa berita untuk memperjelas juga meyakinkan pembaca terhadap realitas yang terjadi. Terlebih pada saat ini, foto bisa dikatakan mampu berbicara lebih dibandingkan dengan susunan kata-kata

Selain itu, membuat framing pemberitaan PKL namun dikemas dalam bentuk infografis. Hal tersebut agar mempermudah dalam menyampaikan termasuk mengkritik apa yang dikehendaki HU Kabar Priangan. Infografis dibuat dengan dukungan foto, data, serta deskripsi yang padat dan jelas.

Bahkan idealnya, media tidak terus-menerus menekan pemerintah melalui kritik bahasa maupun kutipan wawancara. Idealnya, HU Kabar Priangan pun mengkritik inkonsistensi PKL Cihideung yang abai terhadap kesepakatan diawal dengan pemerinntah, juga meminta alasan yang kredibel mengapa tidak ingin direlokasi. Diakhir, HU Kabar Priangan seyogyanya meminta pendapat pengamat/praktisi/pakar/akademisi di bidang kajian penataan kota, ekonomi mikro, dan kebijakan publik dengan tujuan untuk mencari solusi baru yang nantinya bisa dijadikan rekomendasi kepada pemerintah.

\section{REFERENSI}

\section{Buku}

Ardianto, Elvinaro, dkk. (2007). Komunikasi Massa Suatu Pengantar Edisi Revisi. Bandung: Simbiosa Rekatama Media.

Eriyanto. (2009). Analisis Framing Konstruksi, Ideologi, dan Politik Media. Yogyakarta: PT LkiS Printing Cemerlang

H.I, A Rahman. (2007). Sistem Politik Indonesia. Yogyakarta: Graha Ilmu.

Simarmata, Salvatore. (2014). Media dan Politik. Jakarta: Yayasan Pustaka Obor Indonesia. Insist. (2015). Orde Media Kajian Televisi dan Media di Indonesia Pasca Orde Baru. Yogyakarta: INSISTPress.

Ishwara, Luwi. (2016). Jurnalisme Dasar. Jakarta: PT Kompas Media Nusantara.

Parsons, Wayne. (2014). Public Policy: Pengantar Teori dan Praktik Analisis Kebijakan Publik. Jakarta: Kencana Prenadamedia Group.

M. Poloma, Margaret. (1984). Sosiologi Kontemporer. Jakarta: CV. Rajawali.

Sobur, Alex. (2012). Analisis Teks Media Suatu Pengantar Untuk Analisis Wacana, Analisis Semiotik, dan Analisis Framing. Bandung: PT Remaja Rosdakarya.

Uchjana Effendy, Onong. (2005). Ilmu Komunikasi Teori dan Prakterk. Bandung: PT Remaja Rosdakarya.

\section{Karya Tulis}

Ibrahim, Ahmad. (2004). Legalitas dan Masa Depan Pedagang Kaki Lima dalam Kebijakan Perekonomian di Indonesia. Makalah. Tasikmalaya: Sekolah Tinggi Hukum Galunggung

Nur Amaliyah, Siti. (2016). Bingkai Media Terhadap Berita Mengenai Ahok Dalam Pilkada DKI Jakarta 2017. Tesis. FISIP Universitas Sebelas Maret. Surakarta. Diambil dari https://eprints.uns.ac.id/31905/ 
Silvana, Hana. (2013). Peran Media Massa Pada Komunikasi Politik di Indonesia. Jurnal. FISIP Ilmu Komunikasi Universitas Langlangbuana. Bandung. Diambil dari Jurnal JIPSI, 2013, https://s3.amazonaws.com/academia.edu.documents

\section{Media}

Jani Noor, HU Kabar Priangan. (2017). Cihideung Semrawut, Kotor, dan Kumuh. Senin, 10 April 2017. Hal 1 dan 7.

Wartamerdeka.com, Pemkot Tasik Dinilai Aneh, PKL di Hazet Dilarang Berjualan Tapi di Cihideung Diberi Bantuan, diakses pada 05 September 2017.

Harian Umum Kabar Priangan edisi Senin, 10 April 2017

Harian Umum Kabar Priangan edisi Jumat, 21 Juli 2017, kolom Kota Tasikmalaya

Harian Umum Kabar Priangan edisi Kamis, 7 September 2017 